\title{
PROFIL PROTEIN DAGING IKAN KURISI MERAH (Pagrus major) YANG DIBERI PAKAN DENGAN TAMBAHAN TEPUNG DAUN ZAITUN (Olea europaea L.)
}

\author{
Muh Ali Arsyad dan Arham Rusli \\ Program Studi Teknologi Pengolahan Hasil Perikanan, Politeknik Pertanian Negeri Pangkajene \\ dan Kepulauan, Jalan Poros Makassar-Pare Km.83 Pangkep, Sulawesi Selatan 90655. \\ Telp (0410) 2312703; 2312704, Faksimile: (0410) 2312705 \\ *Korespondensi: muh.aliarsyadabdullah@gmail.com\ \\ Diterima: 31 Maret 2020 / Disetujui: 30 April 2020
}

Cara sitasi: Arsyad MA, Rusli A. 2020. Profil protein daging ikan kurisi merah (Pagrus major) yang diberi pakan dengan tambahan tepung daun zaitun (Olea europaea L.). Jurnal Pengolahan Hasil Perikanan Indonesia. 23(1): 93-102.

\begin{abstract}
Abstrak
Pemberian pakan dengan tambahan antioksidan dari bahan alam terbukti mampu meningkatkan kualitas daging yang dihasilkan. Aktivitas antioksidan dari bahan alam ditentukan oleh kandungan polifenol. Daun zaitun mengandung 6-9\% polifeneol. Penelitian ini bertujuan untuk menentukan pengaruh penambahan tepung daun zaitun pada pakan terhadap profil protein daging ikan yang dikultur selama 25 hari pada akuarium dengan kondisi yang terkontrol. Komposisi protein daging dianalisis dengan SDS-PAGE dan kandungan protein sarkoplasma, miofibril dan kolagen dianalisa dengan metode biuret. Kandungan protein sarkoplasma dan miofibril tidak berbeda pada kedua kelompok ikan, tetapi kandungan kolagen daging ikan yang diberi pakan dengan tepung daun zaitun 1,63 kali lebih tinggi dibanding ikan dengan pakan kontrol. Mikrostruktur daging ikan dengan pakan tepung daun zaitun lebih kompak dibanding ikan dengan pakan kontrol, hal tersebut disebabkan kandungan kolagen yang lebih tinggi. Hasil penelitian ini menunjukkan bahwa penambahan tepung daun zaitun pada pakan mampu meningkatkan tekstur pada daging melalui peningkatan kuantitas dan kualitas serat kolagen pada endomisium.
\end{abstract}

Kata kunci: miofibril, kolagen, polifenol, sarkoplasma, struktur daging

\section{Profile Protein of Fish Red Sea Bream (Pagrus major) Muscle Fed with Additional Olive (Olea europaea L.) Leaf Powder}

\begin{abstract}
Feeding with the addition of antioxidants from natural ingredients is proven to be able to improve the quality of the meat product. The antioxidant activity of natural ingredients is determined by the content of polyphenols. Olive leaves contain 6-9\% of polyphenols. This study aimed to determine the effect of addition of olive leaf powder to feed on the structure of protein in fish meat that is cultured for 25 days in an aquarium under controlled conditions. The composition of meat protein was analyzed by SDSPAGE and the protein content of sarcoplasmic, myofibrils and collagen was determined by biuret method. Sarcoplasmic and myofibril protein contents did not differ much in the two groups of fish, but the collagen content of fish meat fed with olive leaf powder was 1.63 times higher than that of fish with control feed. Fish meat microstructure with olive leaf powder is more rigid than fish with control feed, this is due to the higher collagen content. The results of this study suggest that the addition of olive leaf powder to the feed improves the texture of meat, by increasing the quantity and quality of collagen fibers in endomysium.
\end{abstract}

Keywords: collagen, meat structure, myofibril, polyphenols, sarcoplasmic 


\section{PENDAHULUAN}

Kualitas daging ikan ditentukan oleh struktur protein pada daging tersebut. Pakan menjadi salah satu faktor penting dalam menghasilkan struktur protein daging dari usaha budidaya ikan. Antioksidan sintetik seperti ethoxyquin (EQ), dibutylhydroxytoluene (BHT) and butylhydroxyanisol (BHA) diizinkan untuk ditambahkan pada pakan untuk melindungi dari oksidasi, sebab komposisi pakan banyak mengandung protein dan lemak yang mudah teroksidasi. Pakan yang telah teroksidasi akan menghasilkan kualitas daging yang buruk bahkan bisa menjadi racun bagi ikan (Morrissey et al. 1998). BHT mampu menghambat oksidasi pada pakan (Rudzińska et al. 2007) dan penambahan BHA dan BHT pada pakan juga mampu meningkatkan oxidative stability daging broiler (Lin et al. 1989). Penggunaan antioksidan sintetik memiliki sifat karsinogenik, BHA terbukti memicu tumor pada hati dan BHT menjadi penyebab tumor pada lambung (Kahl 1984). EQ, BHT dan BHA ditemukan pada fillet salmon yang telah diberi pakan dengan antioksidan sintetik (Lundebyea et al. 2010). Persoalan tersebut menyebabkan menurunnya penggunaan sintetik antioksidan dan meningkatnya keinginan para peneliti untuk mencari alternatif antioksidan dari bahan alam yang lebih murah dan aman dari prospektif keamanan pangan. Beberapa bahan alam terbukti memiliki sifat antioksidatif sebagai feed additive seperti daun teh dan rosemary. Suplementasi teh hijau pada ikan ekor kuning dapat menekan akumulasi lipid pada daging (Nakagawa et al. 2007) dan pemberian pakan dengan polifenol dari daun teh meningkatkan oxidative stability pada daging ikan yellow croaker (Larimichthys crocea) tanpa memberikan pengaruh negatif terhadap pertumbuhan (Ji et al. 2017). Aktivitas antioksidan pada bahan alam sangat erat kaitannnya dengan kandungan polifenol, semakin tinggi kandungan polifenol maka semakin besar pula aktivitas antioksidannya Daun zaitun kering mengandung 6-9\% polifenol (Ghanbari et al. 2012) menyebabkan tingginya aktivitas antioksidan (Mkaouar et al. 2018). Pemanfataan limbah dari proses ekstraksi minyak zaitun sebagai feed additive telah dibuktikan mampu meningatkan oxidative stability pada daging ikan yang dihasilkan. Daun zaitun mampu menekan proses pembusukan daging hitam ikan ekor kuning (Seriola quinqueradiata) selama penyimpanan beku (Oyama et al. 2017) dan filet ikan rainbow trout yang diberi pakan dengan limbah cair dari proses ektraksi minyak zaitun memiliki aktivitas antioksidan (Sicuro et al. 2010). Suplementasi antioksidan dari bahan alam juga mampu memperbaiki tekstur daging melalui peningkatan kolagen. Daging ikan sidat (Anguilla japonica) yang telah diberi pakan tepung daun tochu memiliki protein kolagen larut air 1,9 kali lebih tinggi dan tekstur 1,8 kali lebih keras dibanding yang diberi pakan tanpa daun tochu (Tanimoto et al. 1993) dan polifenol dari daun teh hijau pada pakan mampu meningkatkan tekstur ikan ekor kuning muda (Seriola lalandi) (Sato 2007). Peningkatan kandungan kolagen pada daging ikan terbukti memberikan kontribusi terhadap perbaikan tekstur, daging ikan dengan kandungan kolagen yang tinggi memiliki tekstur daging yang lebih keras. Hasil penelitian tersebut di atas memberikan dugaan bahwa penambahan daun zaitun pada pakan mampu meningkatkan tekstur daging ikan melalui peningkatan kandungan kolagen. Tujuan penelitian ini adalah mengetahui pengaruh penambahan tepung daun zaitun pada pakan terhadap struktur proteinmiofibril, sarkoplasma dan kolagen pada daging ikan.

\section{BAHAN DAN METODE Bahan dan Alat}

Bahan yang digunakan adalah daun zaitun segar didapatkan langsung dari pohon zaitun (Olea europaea L.) yang tumbuh di Fakultas Pertanian, Universitas Kagawa Jepang, pakan berupa meat pie (Repash Super food), ikan kurisi merah (panjang $\pm 2 \mathrm{~cm}$ ) diperoleh dari Yoshikawa Suisan Co., Ltd., Kagawa, Jepang, wadah pemeliharaan ikan adalah akuarium transparan kapasitas $50 \mathrm{~L}$ yang dilengkapi dengan lampu LED dan pemanas untuk menjaga suhu air $25^{\circ} \mathrm{C}$ serta artificial sea water (Instant ocean). Alat yang digunakan adalah pengering udara dingin (Cool Dry Machinery Co., Ltd., Kagawa, Japan), scanning electron 
microscope (JCM-6000, JEOL Ltd., Tokyo, Japan), blender (Model FM-700 G, Iwatani, Co., Tokyo, Japan), filter nilon (diameter 108$\mu \mathrm{m})$, beads crusher ( $\mu \mathrm{T}-01$, TAITEC Corp., Saitama, Japan), spectrofluorometer (FP-6200, Jasco Ltd., Tokyo, Japan), spectrophotometer (V-630, Jasco Ltd., Tokyo, Japan) dan homogenizer (Nissei AM-8, Nihonseiki Kaisha Ltd, Tokyo, Japan).

\section{Metode Penelitian \\ Pembuatan tepung daun zaitun}

Daun zaitun segar (20 g) dikeringkan pada suhu $25-40^{\circ} \mathrm{C}$ selama 48 jam di pengering udara dingin, digiling menggunakan blender dan selanjutnya disaring menggunakan nylon mesh filter (ukuran diameter $108 \mu \mathrm{m}$ ). Tepung hasil penyaringan digunakan sebagai tepung daun zaitun pada penelitian ini.

\section{Pembuatan pakan dengan tambahan tepung daun zaitun}

Tepung daun zaitun (TDZ) dikukus terlebih dahulu untuk menginaktifkan enzim endogen yang bisa mengoksidasi dan mendegradasi senyawa fenol. TDZ yang sudah dikukus ditambahkan ke meat pie dan air panas. Campuran pakan dan TDZ tersebut diaduk hingga membentuk gel, selanjutnya dipotong kecil berbentuk bulat (diameter $\pm 0,2$ $\mathrm{cm}$ ) dan dikeringanginkan pada suhu ruang selama 12 jam. Pakan kontrol dibuat dengan cara yang sama tanpa penambahan TDZ (Table 1).

Table 1 Formula of feed

\begin{tabular}{rcc}
\hline Composition & Ct-Feed & OLP-Feed \\
\hline Meat pie $^{\star}(\mathrm{g})$ & 10.0 & 10.0 \\
Olive leaf powder $(\mathrm{g})$ & 0.5 & - \\
Hot water $(\mathrm{ml})$ & 29.5 & 30.0 \\
\hline
\end{tabular}

${ }^{*}$ Composition of protein, fat, fiber, ash, calcium, and moisture was $45 ; 8 ; 5 ; 13 ; 1,5$; and $6 \%$ respectively

Rasio penambahan TDZ terhadap meat pie adalah 5\%. Kandungan polifenol pakan kontrol adalah 0,09 mg/g dan pakan+TDZ adalah $0,18 \mathrm{mg} / \mathrm{g}$. Oleuropein adalah senyawa fenol yang dominan pada daun zaitun, ditemukan pada Pakan+TDZ yaitu 76,30 ppm dan tidak ditemukan pakan kontrol.

\section{Pemeliharaan ikan kurisi merah}

Sebanyak 20 ekor ikan kurisi merah dengan panjang rata-rata $\pm 3 \mathrm{~cm}$ dibagi ke dalam 2 kelompok akuarium (50 L), yaitu kelompok ikan yang diberi pakan+TDZ dan kelompok ikan yang diberi pakan tanpa TDZ (Pakan kontrol). Ikan dipelihara selama 25 hari dalam artificial sea water dengan frekuensi pemberian pakan sebanyak 1 kali dalam sehari. Selama masa pemeliharaan ratarata suhu air $25,0 \pm 0,11^{\circ} \mathrm{C}, \mathrm{pH} 7,4 \pm 0,5$ dan spesific gravity adalah $1,022 \pm 0,001$.

\section{Koleksi sampel daging ikan}

Setelah masa pemeliharaan selama 25 hari, ikan dipanen selanjutnya ditimbang dan diukur panjang standar. K-faktor dihitung berdasarkan metode yang dikembangkan oleh Mozsár et al. (2015) dengan persamaan sebagai berikut:

K-faktor $=\frac{\text { Berat basa }(\mathrm{g})}{\text { Panjang standar }(\mathrm{cm})^{3}} \times 100 \%$

Dua belas ikan, masing masing 6 ikan dari kelompok ikan dengan pakan+TDZ dan 6 ikan dari kelompok ikan dengan pakan kontrol yang memiliki nilai K-faktor yang sama dijadikan sebagai sampel. Ikan selanjutnya difilet dan bagian daging dorsal dijadikan sampel untuk dianalisis secara kimiawi.

\section{Kandungan air daging}

Daging dorsal (0,5 g) ditempatkan pada pan aluminium foil dan selanjutnya didehidrasi di oven pada suhu $105 \pm 1^{\circ} \mathrm{C}$ selama 12 jam. Daging yang telah didehidrasi ditempatkan pada desikator dan selanjutya ditimbang menggunakan timbangan elektrik. Kandungan air pada daging dihitung menggunakan persamaan berikut:

$$
\text { Kandungan air }(\%)=\frac{(W i-W f)}{W i} \times 100
$$

dimana, $\mathrm{W}_{\mathrm{i}}$ adalah berat daging sebelum didehidrasi dan $\mathrm{W}_{\mathrm{f}}$ berat akhir daging setelah didehidrasi. 


\section{Ekstraksi protein sarkoplasma larut air dan kolagen larut asam}

Daging dorsal $(1,0 \mathrm{~g})$ dihomogenkan dalam

$5 \mathrm{~mL}$ akuades menggunakan homogenizer selama 1 menit. Sampel yang sudah homogen disentrifugasi pada $10.000 \quad g$ selama 20 menit. Supernatan yang dihasilkan adalah protein sarkoplasma larut air. Konsentrasi protein sarkoplasma larut air ditentukan menggunakan metode biuret (Dorey dan Draves 1998). Endapan dari proses ekstraksi protein sarkoplasma larut air adalah fraksi tidak larut air yang digunakan untuk ekstraksi kolagen larut asam. Ekstraksi kolagen larut asam dilakukan berdasarkan metode yang dikembangkan oleh Sato et al. (1987) dengan sedikit modifikasi. Dua puluh mililiter larutan $0,1 \mathrm{~N} \mathrm{NaOH}$ ditambahkan pada endapan dari proses ektraksi protein sarkoplasma dan dihomogen menggunakan homogenizer. Larutan sampel yang sudah homogen selanjutnya disentrifugasi pada $10.000 \mathrm{~g}$ selama 20 menit. Proses pencucian alkali pada sampel dilakukan sebanyak 3 kali ulangan. Endapan yang dihasilkan selanjutnya diekstraksi dalam $10 \mathrm{ml}$ larutan $0,5 \mathrm{M}$ asam asetik dengan pengadukan secara terus menerus selama 72 jam menggunakan magnetic stirrer selanjutnya disentrifugasi pada kecepatan $10.000 \mathrm{~g}$ selama 20 menit. Endapan dari proses sentrifugasi diekstraksi kembali dalam larutan yang sama selama 48 jam dan selanjutnya disentrifugasi pada kecepatan $10.000 \mathrm{~g}$ selama 20 menit. Supernatan yang dihasilkan dari 2 kali proses ekstraksi digabung sebagai kolagen larut asam. Kosentrasi kolagen larut asam dihitung menggunakan Sirius-Red berdasarkan metode yang dikembangkan oleh Kliment et al. (2011) dengan sedikit modifikasi. Satu mililiter staining agent (direct red 80 dalam asam pikrik) ditambahkan ke sampel $(100 \mu \mathrm{L})$ selanjutnya disenrifugasi pada kecepatan $10.000 \mathrm{~g}$ selama 10 menit. Satu mililiter larutan $0,5 \mathrm{M} \mathrm{NaOH}$ ditambahkan pada endapan dan larutan warna yang dihasilkan dipindahkan ke sumur 96-well plate selanjutnya absorban diukur pada panjang gelombang $550 \mathrm{~nm}$ dengan spektrophotometer. Konsentrasi kolagen dihitung menggunakan kolagen larut asam dari kulit babi sebagai standard $(0,2-1,0 \mathrm{mg} /$ $\mathrm{mL}$ dalam 0,5 $\mathrm{M}$ asam asetik).

\section{Ekstraksi protein miofibril}

Seluruh prosedur ekstraksi protein miofibril dilakukan dibawah suhu $4^{\circ} \mathrm{C}$ berdasarkan metode Jiang et al. (2006) dengan sedikit modifikasi. Daging dorsal (1,5 g) dihaluskan dan kemudian dihomogenkan dalam $4 \mathrm{~mL}$ larutan $20 \mathrm{mM}$ sodium phosphate buffer ( $\mathrm{pH} 7,5)$ menggunakan homogenizer pada kecepatan 4.500 rpm selama 30 detik. Proses homogenisasi dilakukan sebanyak 2 kali dengan interval waktu 1 menit. Larutan sampel disentrifugasi pada kecepatan $8.000 \mathrm{~g}$ pada suhu $4^{\circ} \mathrm{C}$ selama 10 menit. Supernatan yang dihasilkan dibuang dan endapan kembali dihomogenkan dalam $4 \mathrm{~mL}$ pada larutan yang sama. Setelah proses homogenisasisentrifugasi dilakukan 3 kali, endapan yang didapatkan selanjutnya dilarutkan dalam $4 \mathrm{~mL}$ larutan $20 \mathrm{mM}$ sodium phosphate buffer $(\mathrm{pH}$ 8,0 ) yang mengandung $0,5 \mathrm{M} \mathrm{NaCl}$. Larutan tersebut adalah protein myofibril. Konsentrasi protein miofibril dihitung dengan metode biuret menggunakan BSA sebagai standar (Dorey dan Draves 1998).

\section{Kandungan hidroksiprolin}

Daging dorsal $(0,5 \mathrm{~g})$ dihomegenkan dalam $0,5 \mathrm{~mL}$ aquades menggunakan beads crusher pada kecepatan $4.500 \mathrm{rpm}$ selama 60 detik. Proseshomogenisasidilakukan sebanyak 2 kali. Sampel selanjutnya ditempatkan pada aluminum foil dan dikeringkan dalam oven pada suhu $90+1^{\circ} \mathrm{C}$ selama 24 jam. Sampel yang telah kering dihaluskan menggunakan beads crusher pada kecepatan 4.500 rpm selama 60 detik. Proses penghalusan sampel diulang 3 kali. Hidrolisis alkalin pada sampel dilakukan berdasarkan metode yang dikembangkan oleh (Maria et al. 2015). Tepung kering sampel $(5 \mathrm{mg})$ dicampur dengan $500 \mu \mathrm{L}$ larutan $7 \mathrm{~N} \mathrm{NaOH}$ dalam tabung kru tertutup dan selanjutnya ditempatkan pada autoclaf dengan suhu $121^{\circ} \mathrm{C}$ selama 20 menit. $\mathrm{PH}$ hidrolisat alkalin ditetapkan ke $\mathrm{pH}$ 8,0 dengan penambahan $1 \mathrm{~N} \mathrm{H}_{2} \mathrm{SO}_{4}$ selanjutnya ditambahkan aquades hingga volume menjadi $10 \mathrm{~mL}$. Kandungan hidroksiprolin ditentukan berdasarkan metode (Nagatani et al1986), 2,0 $\mathrm{mL}$ hidrolisat dicampur dengan 2,0 $\mathrm{g}$ $\mathrm{KCl}$ dan 1,0 mL 0,5 M bufer borat ( $\mathrm{pH} \mathrm{8,2).}$ Larutan tersebut diinkubasi pada suhu $25^{\circ} \mathrm{C}$ 
selama 15 menit dan selanjutnya didinginkan dalam es selama 15 menit. $1,0 \mathrm{~mL}$ larutan 0,2 M kloramin $\mathrm{T}$ dalam 2-methoxyethanol ditambahkan ke dalam larutan tersebut dan diinkubasi dalam es selama 2 jam. Setelah inkubasi, ditambahkan 2,0 mL larutan 3,6 $M$ sodium tiosulfat, dipanaskan pada suhu $100^{\circ} \mathrm{C}$ selama 30 menit dan selanjutnya didinginkan dengan air mengalir selama 5 menit. Larutan tersebut kemudian dicampur dengan tolun $(3,0 \mathrm{~mL})$ and diaduk selama 20 menit sebelum disentrifugasi pada kecepatan $320 \mathrm{~g}$, suhu $10^{\circ} \mathrm{C}$ selama 15 menit. Supernatan $(2,0 \mathrm{~mL})$ dicampur dengan $0,8 \mathrm{~mL}$ Ehrlich's reagent dan diinkubasi pada suhu $25^{\circ} \mathrm{C}$ selama 30 menit kemudian absorbansinya diukur pada panjang gelombang $560 \mathrm{~nm}$. Kandungan hidroksiprolin sample ditentukan dengan faktor konversi yang didapatkan dari standar kurva menggunakan konsentrasi L-hydroxyproline $(1,0-4,0 \mu \mathrm{g} / \mathrm{mL})$.

\section{Profil protein dengan analisis SDS- PAGE}

Sodium dodecyl sulfate-polyacrylamide gel electrophoresis (SDS-PAGE) dilakukan berdasarkan metode Laemmli (1970) dengan sedikit modifikasi. Kolagen larut asam (40 $\mu \mathrm{l})$ dinetralkan dengan penambahan $10 \mu \mathrm{L}$ larutan 1,14 $\mathrm{M} \mathrm{NaHCO}_{3}$. Kolagen yang telah dinetralkan $(50 \mu \mathrm{L})$, larutan miofibril $(50 \mu \mathrm{L})$ dan sarkoplasma larut air $(50 \mu \mathrm{L})$ masing masing ditambahkan dengan 12,5 $\mu \mathrm{L}$ SDS sampel bufer (100 mM Tris-HCl bufer; $\mathrm{pH}$ 6,7; mengandung 5,0\% SDS; 0,004\% bromofenol blue dan 2,0\% $\beta$-mercaptoethanol). Setiap larutan tersebut dipanaskan pada suhu $90^{\circ} \mathrm{C}$ selama 5 menit. $10 \mu \mathrm{L}$ dari setiap larutan dimasukkan ke sumur 10\% gel akrilamid SDSPAGE. Gel yang dihasilkan diwarnai dengan 0,025\% coomassie brilliant blue R-250.

\section{Aktivitas kolagenase}

Seluruh prosedur dilakukan pada suhu dibawah $4^{\circ} \mathrm{C}$. Daging dorsal $(0,2 \mathrm{~g})$ dihomogenkan dalam 5,0 mL larutan $5 \mathrm{mM}$ $\mathrm{CaCl}_{2}-50 \mathrm{mM}$ buffer Tris-HCl ( $\mathrm{pH}$ 8,0) selama 1 menit menggunakan homogenizer. Sampel yang sudah homogen disentrifugasi pada $10.000 \mathrm{~g}$ selama 30 menit. Supernatan yang dihasilkan dikoleksi dan endapannya dihomogen-sentfugasikan kembali seperti prosedur sebelumnya. Supernatan yang dihasilkan kemudian digabung dengan supernatan dari prosedur sebelumnya. Aktivitas kolagenase dari larutan protein tersebut diukur menggunakan substrat sintetik MOCAc-Pro-Leu-Gly-Leu-A 2 pr(DNP)Ala-Arg- $\mathrm{NH}_{2}$, berdasarkan metode yang dikembangkan oleh Itoh et al. (1997) dengan sedikit modifikasi. Substrat sintetik diencerkan dengan larutan dimethyl sulfoxide (DMSO) hingga mecapai 0,04 mM. Sintetik substrat yang telah diencerkan $(0,05 \mathrm{~mL})$ dilarutkan dalam $0,8 \mathrm{~mL}$ larutan $50 \mathrm{mM}$ buffer Tris- $\mathrm{HCl}(\mathrm{pH} 7,5)$ yang mengandung $0,1 \mathrm{M} \mathrm{NaCl}, 10 \mathrm{mM} \mathrm{CaCl}$, dan 0,05\% Brij35 , selanjutnya diinkubasi pada suhu $25^{\circ} \mathrm{C}$ selama 5 menit. Sintetik substrat yang telah dilarutkan selanjutnya direaksikan dengan larutan protein $(0,05 \mathrm{~mL})$ pada suhu $25^{\circ} \mathrm{C}$ selama 10 jam. Reaksi dihentikan dengan penambahan $0,1 \mathrm{~mL}$ larutan $0,1 \mathrm{mM}$ EDTA. Besarnya kuantitas MOCAc-Pro-Leu-Gly yang dihasilkan dari substrat diestimasi dengan mengukur intensitas fluorescent pada $328 \mathrm{~nm}$ (excitation) dan $393 \mathrm{~nm}$ (emission). Pengukuran besarnya reaktan MOCAc-ProLeu-Gly pada larutan dihitung meggunakan faktor konversi yang diperoleh dari kurva standar dari konsentrasi MOCAc-Pro-LeuGly $(0,5-2,0 \mu \mathrm{M})$. Satu unit aktivitas kolagenase diartikan sebagai besarnya kolagenase yang mengkatalisis perubahan $1 \mu \mathrm{M}$ substrat permenit pada suhu $25^{\circ} \mathrm{C}$.

\section{Mikrostruktur daging dorsal}

Mikrostruktur daging dorsal diamati dengan scanning electron microscopy (SEM). Persiapan sampel dilakukan berdasarkan metode (Arsyad 2018a). Daging dorsal dengan ketebalan $5 \mathrm{~mm}$ direndam dalam larutan $0,5 \mathrm{M}$ sodium fosfat bufer $(\mathrm{pH} 7,2)$ yang mengandung 2,5\% glutaraldehid selama 7 hari. Sampel selanjutnya direndam lagi dalam $2 \mathrm{M} \mathrm{NaOH}$ selama 7 hari dilanjutkan dalam 0,5 $\mathrm{M}$ sodium fosfat bufer $(\mathrm{pH} 7,2)$ yang mengandung $1 \%$ osmium selama 2 jam. Sampel yang telah direndam didehidrasi dengan etanol sebelum dikeringbekukan. 
Sampel kemudian diamati menggunakan scanning electron microscope pada tegangan akselerasi $15 \mathrm{kV}$.

\section{Analisis Data}

Analisis statistik dilakukan dengan one-way analysis of variance (Anova) dan perbedaan rata-rata dihitung dengan Duncan multiple range test dengan level perbedaan signifikan 95\% menggunakan perangkat lunak SPSS 15.0 (SPSS Inc., Chicago, IL, USA). Data yang ditampilkan adalah rata-rata dan standar deviasi dari paling sedikit 3 kali ulangan dari setiap kelompok.

\section{HASIL DAN PEMBAHASAN Performa pertumbuhan}

Pengaruh penambahan tepung daun zaitun (TDZ)/olive leafpowder (OLP) terhadap performa pertumbuhan ikan disajikan pada Table 2.

Table 2 Growth performance of control-feed fish and OLP-feed fish

\begin{tabular}{ccc}
\hline Parameter & $\begin{array}{c}\text { Ct-Feed } \\
(\mathrm{n}=7)\end{array}$ & $\begin{array}{c}\text { OLP-Feed } \\
(\mathrm{n}=7)\end{array}$ \\
\hline Body weight $(\mathrm{g})$ & $5.12 \pm 0.30^{\mathrm{a}}$ & $5.05 \pm 0.12^{\mathrm{a}}$ \\
Standard length $(\mathrm{cm})$ & $7.10 \pm 1.12^{\mathrm{a}}$ & $6.80 \pm 1.50^{\mathrm{a}}$ \\
K-Factor $(\mathrm{g} / \mathrm{cm} 3)$ & $1.43 \pm 0.21^{\mathrm{a}}$ & $1.61 \pm 0.04^{\mathrm{a}}$ \\
\hline
\end{tabular}

Data are presented as mean $\pm \mathrm{SD}$, and different superscript letters in a line show the significant differences $(\mathrm{P}<0.05)$.

Performa pertumbuhan ikan yang diberi pakan dengan tambahan TDZ tidak berbeda nyata dengan ikan yang diberi pakan tanpa tambahan TDZ. Hasil tersebut sejalan dengan hasil penelitian (Sicuro et al. (2010) yang melaporkan bahwa ikan yang diberi pakan hasil samping dari proses ekstraksi minyak zaitun sedikit lebih kecil dibanding dengan ikan yang diberi pakan kontrol. Penelitian ini difokuskan pada pengaruh penambahan TDZ pada pakan terhadap struktur protein daging ikan, bukan pada kinerja pertumbuhan.

\section{Kandungan protein}

Hasil analisis SDS-PAGE (Figure 1) menunjukkan bahwa protein fraksi larut air yang diekstrak dari daging ikan yang diberi pakan tanpa penambahan TDZ memiliki pola yang sama dengan ikan yang diberi pakan dengan penambahan TDZ (Figure 1.a). Pita yang dihasilkan dari fraksi protein larut air menunjukkan bahwa tipe protein tersebut adalah sarkoplasma. Band SDS-PAGE yang dihasilkan dari fraksi protein larut garam (Figure1.b) menunjukkan bahwa tipe protein tersebut adalah miofibril seperti myosin heavy chain $(200 \mathrm{kDa})$, actin $(40 \mathrm{kDa})$ dan troponin $(30 \mathrm{kDa})$. Pola dan intensitas serta berat molekul protein fraksi larut garam tidak berbeda antara dua kelompok ikan. Figure 1.c menunjukkan bahwa kolagen larut asam yang diekstrak dari dua kelompok ikan menunjukkan pola yang sama yakni dua pita $\alpha$ yang berbeda yaitu $\alpha_{1}$ dan $\alpha_{2}$ dengan berat molekul masing-masing 130 dan $120 \mathrm{kDa}$ dan pita $\beta$ dengan berat molekul sekitar 200 $\mathrm{kDa}$. Pola distribusi pita kolagen larut asam menunjukkan bahwa tipe kolagen utama pada daging ikan adalah kolagen tipe 1 (Arsyad et al. 2018b). Hasil analisis SDS-PAGE menunjukkan bahwa penambahan TDZ pada

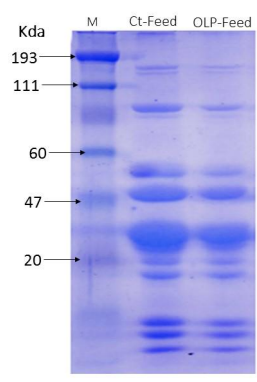

(a)

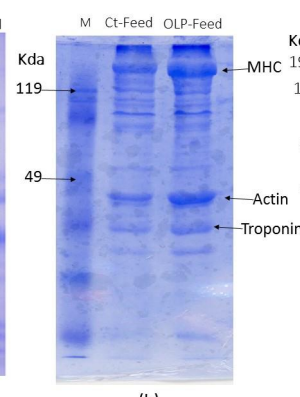

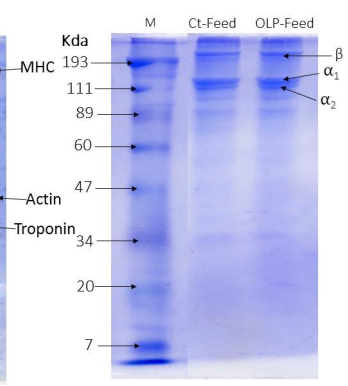

(c)

Figure 1 SDS-PAGE pattern of (1) sarcoplasmic water-soluble protein, (2) myofibril protein, and (3) acidsoluble collagen. Marker, M; Myosin heavy chain, MHC; $\alpha 1$ chain of collagen, $\alpha 1$; $\alpha 2$ chain of collagen, $\alpha 2$; and $\beta$ chain of collagen, $\beta$. 
pakan ikan tidak memberikan pengaruh terhadap pola protein yang diekstrak dari daging dorsal ikan.

Kandungan air dan kandungan protein masing-masing fraksi yang diekstrak dari daging dorsal ikan disajikan pada Table 3. Kandungan protein sarkoplasma dan miofibril daging dorsal hampir sama antara ikan yang diberi pakan dengan tambahan TDZ dan tanpa penambahan TDZ. Kandungan protein kolagen larut asam berbeda nyata pada dua kelompok ikan, kandungan kolagen larut asam pada daging ikan yang diberi pakan dengan tambahan TDZ 1,63 kali lebih besar dari ikan yang diberi pakan tanpa penambahan TDZ. Hasil tersebut membuktikan bahwa penambahan TDZ pada pakan mampu meningkatkan kolagen larut asam pada daging dorsal ikan. Hidroksiprolin adalah asam amino yang hanya ditemukan pada kolagen. Kandungan hidroksiprolin hampir sama pada dua kelompok ikan yang berbeda. Kandungan air pada dua kelompok ikan yang berbeda juga hampir sama. Meskipun ada kesamaan pada kandungan protein sarkoplasma, miofibril, hidroksiprolin, kadar air pada dua kelompok ikan yang berbeda, tetapi kandungan kolagen larut asam ditemukan lebih tinggi pada ikan yang diberi pakan dengan tambahan TDZ.
Sehingga penambahan TDZ pada pakan terbukti mampu meningkatkan protein kolagen larut asam dalam penelitian ini.

Kandungan kolagen lebih tinggi ditemukan pada daging dorsal dari ikan yang diberi pakan dengan tambahan TDZ dibanding dengan ikan dengan pakan tanpa penambahan TDZ, untuk mengetahui penyebab perbedaan tersebut, maka aktivitas kolagenase pada dorsal dari kedua kelompok ikan tersebut dianalisa menggunakan substrat sintetik MOCAc-Pro-Leu-GlyLeu-A2pr(DNP)-Ala-Arg-NH2. Figure 2 menunjukkan bahwa aktivitas kolagenase tidak berbeda nyata antara daging dorsal dari ikan yang diberi pakan dengan tambahan TDZ dengan ikan yang diberi pakan tanpa penambahan TDZ, tetapi aktivitas kolagenase pada ikan dengan pakan TDZ sedikit lebih rendah. Aktivitas kolagenase yang hampir sama antara dua daging dari kelompok ikan yang berbeda menunjukkan bahwa kolagenase tidak memiliki peran yang krusial dalam mempengaruhi kandungan kolagen pada daging. Dalam penelitian ini, substrat sintetik yang digunakan adalah indikator dalam menentukan aktivitas kolagenase. Enzim proteolitik selain kolagenase yang menghidrolisis substrat sintetik mungkin

Table 3 Protein and water content of the dorsal muscle of fish

\begin{tabular}{ccc}
\hline Parameter & Ct-Feed & OLP-Feed \\
\hline Sarcoplasmic protein (mg/g muscle) & $40.85 \pm 5.50^{\mathrm{a}}$ & $41.22 \pm 7.20^{\mathrm{a}}$ \\
Myofibril protein (mg/g muscle) & $92.76 \pm 10.50^{\mathrm{a}}$ & $102.73 \pm 12.10^{\mathrm{a}}$ \\
Acid-soluble collagen (mg/g muscle) & $1.11 \pm 0.20^{\mathrm{a}}$ & $1.81 \pm 0.25^{\mathrm{b}}$ \\
Hydroxyproline (mg/g muscle) & $0.25 \pm 0.01^{\mathrm{a}}$ & $0.28 \pm 0.03^{\mathrm{a}}$ \\
Water content of muscle (\%) & $77.50 \pm 5.50^{\mathrm{a}}$ & $76.85 \pm 8.34^{\mathrm{a}}$ \\
\hline
\end{tabular}

Data are presented as mean $\pm \mathrm{SD}$, and different superscript letters in a line show the significant differences $(\mathrm{P}<0.05)$.

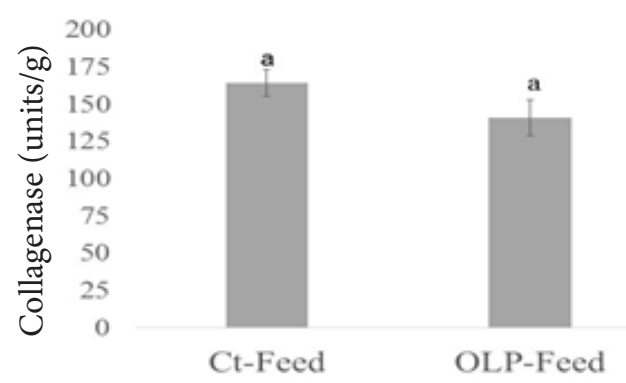

Figure 2 Collagenase activity of protein extracted from the dorsal muscle of fish. Data are presented as mean $\pm S D(n=4)$, and different superscript letters indicate significant difference $(P<0.05)$ 

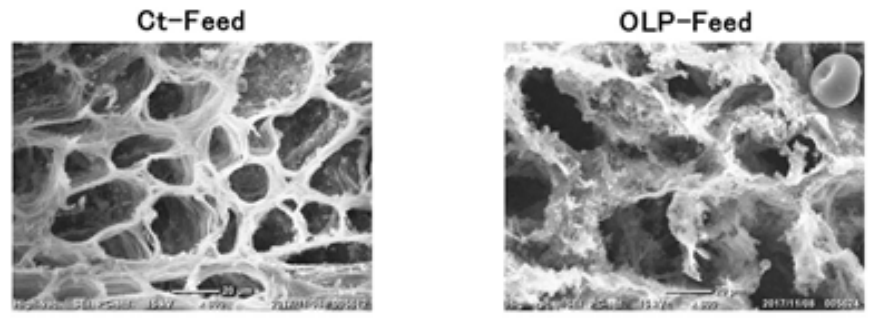

Figure 3 Micrographs of endomysial honeycomb structure of dorsal muscle at x800 magnification, scale bar: $20 \mu \mathrm{m}$

aktivitasnya berkurang pada daging dari ikan dengan pakan TDZ.

\section{Mikrostruktur daging dorsal}

Kandungan kolagen yang diekstrak dari daging ikan dengan pemberian pakan denganTDZ terbukti lebih tinggi dibanding dengan ikan dengan pakan tanpa TDZ. Perbedaan kandungan kolagen tersebut mungkin mempengaruhi struktur jaringan daging, maka mikrostruktur daging dari dua kelompok ikan yang berbeda perlu dianalisa. Struktur endomisium daging dorsal diamati dengan SEM (Figure 3). Daging dorsal dari kedua kelompok ikan yang berbeda memiliki struktur honeycomb endomisial yang sempurna. Namun struktur daging dorsal dari ikan yang diberi pakan denganTDZ memiliki lebih sedikit rongga dengan pori yang lebih kecil dibanding dengan daging dorsal dari ikan yang diberi pakan tanpa TDZ. Kandungan kolagen yang lebih tinggi ditemukan pada daging dengan struktur rongga yang lebih sedikit dan ukuran pori lebih kecil (Cheng et al. 2017). Lapisan endomisum pada daging dorsal ikan yang diberi pakan dengan TDZ lebih tebal dibandingkan pada ikan dengan pakan kontrol. Dari hasil tersebut dapat diduga bahwa TDZ pada pakan mampu meningkatkan lapisan endomisium kolagen pada daging ikan.

Hasil penelitian ini menunjukkan bahwa penambahan tepung daun zaitun pada pakan mampu mengubah struktur protein daging, dengan peningkatan kuantitas dan kualitas serat kolagen pada endomisium. Peningkatan kolagen terbukti memberikan pengaruh terhadap perbaikan tekstur daging (Oyama et al. 2010; Shioya et al. 1996 dan Tanimoto et al. 1993). Perbaikan jaringan ikat kolagen pada daging ikan yang diberi pakan dengan TDZ diduga karena senyawa yang terdapat pada TDZ atau metabolitnya meningkatkan sintetis kolagen pada daging atau menghambat produksi atau aktivitas enzim proteolitik. Penelitian lebih mendalam dibutuhkan untuk menemukan mekanisme tersebut.

\section{KESIMPULAN}

Penambahan TDZ pada pakan mampu meningkatkan kandungan kolagen pada daging ikan. Selanjutnya, mikrostruktur daging dari ikan dengan pemberian pakan dengan TDZ memliki endomisum dengan lapisan yang lebih tebal dibanding ikan dengan pakan kontrol. Hasil penelitian ini menunjukkan bahwa penambahan TDZ pada pakan mampu meningkatkan tekstur pada daging, melalui peningkatan kuantitas dan kualitas serat kolagen pada endomisium.

\section{DAFTAR PUSTAKA}

Arsyad MA, Akazawa T, Nozaki C, Yoshida M, Oyana K, Mukai T, Ogawa M. 2018b. Effects of olive leaf powder supplemented to fish feed on muscle protein of red sea bream. Fish Physiology and Biochemistry. 44(5): 1299-1308.

Arsyad MA, Akazawa T, Ogawa M. 2018a. Effects of olive leaf powder on mechanical properties of heat-induced surimi gel. Journal of Aquatic Food Product Technology. 28(1):2-13

Cheng X, Shao Z, Li C, Yu L, Raja MA, Liu C. 2017. Isolation, characterization and evaluation of collagen from jellyfish Rhopilema esculentum kishinouye for use in hemostatic applications. PLOS ONE. 12(1): 1-21.

DoreyRC, DravesJA.1998.Spectrophotometric determination of total proteinbiuret Method. Quantitative Analysis 
Laboratory: A New Approach Funded by the National Science Foundation. 48(3): $1-3$.

Ghanbari R, Anwar F, Alkharfy K M, Gilani AH, Saari N. 2012. Valuable nutrients and functional bioactives in different parts of olive (Olea europaea L.)-a review. International Journal of Molecular Sciences. 13(3):3291-3340.

Itoh $\mathrm{M}$, Osaki $\mathrm{M}$, Chiba T, Masuda K, Akizawa T, Yoshioka M, Seiki M. 1997. Flow injection analysis for measurement of activity of matrix metalloproteinase-7 (MMP-7)1. Journal of Pharmaceutical and Biomedical Analysis. 15(9-10): 14171426.

Ji R, Li Y, Li X, Xiang X, Li Y, Zhu S,Yang B, Zhang Y, Mai K, Ai Q. 2017. Effects of dietary tea polyphenols on growth, biochemical and antioxidant responses, fatty acid composition and expression of lipid metabolism related genes of large yellow croaker (Larimichthys crocea). 49(3): 1210-1218.

Jiang XJ, Zhang ZJ, Cai HN, Hara K, Su WJ, Cao MJ. 2006. The effect of soybean trypsin inhibitor on the degradation of myofibrillar proteins by an endogenous serine proteinase of crucian carp. Food Chemistry. 94(4): 498-503.

Kahl R. 1984. Synthetic antioxidants: biochemical actions and interference with radiation, toxic compounds, chemical mutagens and chemical carcinogens. Toxicology. 33(3-4): 185-228.

Kliment CR, Englert JM, Crum LP, Oury TD. 2011. Original article a novel method for accurate collagen and biochemical assessment of pulmonary tissue utilizing one animal. International Journal of Clinical and Experimental Pathology. 4(4): 349-355.

Laemmli UK. 1970. Cleavage of structural proteins during the assembly of the head of bacteriophage T4. Nature Publishing. 227: 680-685.

Lin C, Asghar A, Gray TI, Buckley DJ, Booren AM, Crackel RL, Flagel CJ. 1989. Effects of oxidised dietary oil and antioxidant supplementation on broiler growth and meat stability. British Poultry Science.
30(4): 855-864.

Lundebyea AK, Hovea H, Mågea A, Bohneb VJB, Hamrea K. 2010. Levels of synthetic antioxidants (ethoxyquin, butylated hydroxytoluene and butylated hydroxyanisole) in fish feed and commercially farmed fish. Food Additives and Contaminants - Part A Chemistry, Analysis, Control, Exposure and Risk Assessment. 27(12): 1652-1657.

Maria C, Spinelli E, Vianna S. 2015. Fast and sensitive collagen quantification by alkaline hydrolysis / hydroxyproline assay. Food Chemistry. 173: 619-623.

Mkaouar S, Krichen F, Bahloul N, Allaf K, Kechaou N. 2018. Enhancement of bioactive compounds and antioxidant activities of olive (Olea europaea L.) leaf extract by instant controlled pressure drop. Food and Bioprocess Technology. 11: 1222-122.

Morrissey PA, Sheehy PJA, Galvin K, Kerry JP, Buckley DJ. 1998. Lipid stability in meat and meat products. Meat Science. 49(1): S73-S86.

Mozsár A, Boros G, Sály P, Antal L, Nagy SA. 2015. Relationship between Fulton's condition factor and proximate body composition in three freshwater fish species. Journal of Applied Ichthyology. 31(2): 315-320.

Nagatani Y, Muto Y, Sato H, Iijima M. 1986. An improved method for determination of hydroxyproline. Yakogaku Zasshi. 106(1): 41-46.

Nakagawa H, Sato M, Gatlin III DM. 2007. Dietary supplements for the health and quality of cultured fish. www.cabi.org.

Oyama K, Onishi S, Matsuoka H, Touhata K, Ishida N, Ogawa M. 2017. Instrumental analysis of fat content and taste of yellowtail Seriola quinqueradiata raised on a diet supplemented with powdered olive leaves. Nippon Shokuhin Kagaku Kaishi. 64(10): 507-514.

Oyama K, Tochino M, Ueta Y, Takemori H, Tada T. 2010. Effects of a diet supplemented with powdered olive Olea europaea leaf on prevention of dark muscle discoloration in cultured yellowtail Seriola quinqueradiata. 
Aquaculture Science. 58(2): 279-287.

Piluzza G, Bullitta S. 2011. Correlations between phenolic content and antioxidant properties in twenty-four plant species of traditional ethnoveterinary use in the Mediterranean area. Pharmaceutical Biology. 49(3): 240-247.

Rudzińska M, Flaczyk E, Amarowicz R, WąsowiczE, KorczakJ.2007. Antioxidative effect of crackling hydrolysates during frozen storage of cooked pork meatballs. European Food Research and Technology. 224(3): 293-299.

Sato K, Yoshinaka R, Sato M, Shimizu Y 1987. Isolation of native acid-soluble collagen from fish muscle. Nippon Suisan Gakkaishi. 53(8): 1431-1436.
Sato M. 2007. Dietery Supplements for the Health and Quality of Cultured Fish. Wallingford (UK): CAB International.

Shioya M, Maruyama K, Takahashi S, Tanimoto S. 1996. Myofibrils and meat texture of broilers fed on a diet of tochu leaf powder. Bioscience, Biotechnology, and Biochemistry. 60(2): 364-365.

Sicuro B, Daprà F, Gai F, Palmegiano GB, Schiavone R, Zilli L, Vilella S. 2010. Olive oil by-product as a natural antioxidant in gilthead sea bream (Sparus aurata) nutrition. Aquaculture International. 18(4): 511-522.

Tanimoto SY, Koike Ik, Takahashi S. 1993. Improvement in raw meat texture of cultured eel by feeding of tochu leaf powder t. Bioscience, Biotechnology, and Biochemistry. 57(2): 325-327. 